Applied Economics

\title{
Determinants of private savings behaviour in Turkey
}

\section{Kivilcim Metin Ozcan , Asli Gunay \& Seda Ertac}

To cite this article: Kivilcim Metin Ozcan , Asli Gunay \& Seda Ertac (2003) Determinants of private savings behaviour in Turkey, Applied Economics, 35:12, 1405-1416, DOI:

$10.1080 / 0003684032000100373$

To link to this article: http://dx.doi.org/10.1080/0003684032000100373

\section{Published online: 05 Oct 2010.}

Submit your article to this journal

Џlll Article views: 383

Q View related articles $\leftarrow$

4 Citing articles: 21 View citing articles 


\title{
Determinants of private savings behaviour in Turkey
}

\author{
KIVILCIM METIN OZCAN*, ASLI GUNAY and SEDA ERTAC: \\ Bilkent University, Department of Economics, 06533 Ankara, Turkey and \\ $\$$ University of California at Los Angeles, Department of Economics
}

This study investigates the effects on private saving rates of a number of policy and non-policy variables. The analysis covers the period 1968-1994. The empirical private saving model for Turkey is estimated. The findings support the hypothesis that private saving rates have strong inertia. The evidence indicates that government saving does not tend to crowd out private savings and the Ricardian equivalence does not hold strictly. Income level has a positive impact on private saving rate, and growth rate of income is not statistically significant. From a policy point of view, financial depth and development measures in Turkey suggest that countries with deeper financial systems tend to have higher private saving rates. Private credit and real interest rates try to capture the severity of the borrowing constraints and the degree of financial repression for Turkey. Moreover, the negative impact of life expectancy rate lends support to the life-cycle hypothesis. The precautionary motive for saving is supported by the findings that inflation captures the degree of macroeconomic volatility and has a positive impact on private saving in Turkey.

\section{INTRODUCTION}

Along with the recent revival of interest in and the consequent expansion of the literature on economic growth, the behaviour of saving rates also underwent an upsurge in attention. Among other things, the long-debated relationship between savings and the level and growth rate of income has provided a strong stimulus for analysing the determinants of saving more thoroughly. This relation has become even more solid with studies confirming that despite the occasional importance of international flows of capital, the most important factor for a country's investment is indeed its own savings.

A glance at the literature reveals that there emerge two major hypotheses in studying private savings. The first one is the Permanent Income Hypothesis of Friedman (1957). This hypothesis differentiates permanent and transitory components of income as determinants of savings. Permanent income is defined in terms of the long time income expectation over a planning period and transitory income is the difference between actual and permanent income. There are many empirical studies on the permanent income hypothesis in the literature (see, for example, Kelley and Williamson, 1968; Gupta, 1970a, b; and Gupta 1971). The second one is Ando and Modigliani's Life Cycle Hypothesis (1963). According to this hypothesis, individuals spread their lifetime consumption over their lives by accumulating savings during earning years and maintaining consumption levels during retirement. The empirical studies are concerned with the effect of demographic factors, such as age groups (Kelley and Williamson, 1968), birth rates (Leff, 1969, 1971), dependency ratios (Gupta, 1971), financial variables such as interest rates (Ouliaris, 1981) and inflation rates (Koskela and Viren, 1982) on the saving behaviour.

Although studies on savings for groups of countries and regions are relatively abundant (see, for instance, Edwards, 1996; Muradoglu and Taskin, 1996; Dayal-Gulhati and

*Corresponding author. E-mail: kivilcim@bilkent.edu.tr 
Thimann, 1997; and Metin-Ozcan and Ozcan, 2000), the focus has seldom been a specific country (Ortmeyer, 1985). Recently, Aron and Muellbauer 2000 presented the determinants of private saving in South Africa, separately examining personal and corporate sector saving behaviour over nearly three decades, from the late 1960s to 1997 . Their paper confirms that the main factors behind personal saving in South Africa include direct negative effects of wealth and of financial liberalization and the direct positive effects of real interest rates and uncertainty. Moreover, corporations save more when dividend tax rates rise, while in the absence of capital gains tax, higher inflation raises corporate saving.

Considering that most - if not all - studies on savings behaviour have, to some extent, been plagued by lack of or inaccuracies in data, it is apparent that casting the spotlight onto one specific country - especially on one with relatively more reliable data - would be of considerable assistance in drawing a fuller picture of the complex relationship between the saving rate and its determinants. Among developing countries, Turkey can be considered to be a reasonably good choice in this respect, as it is one of the few for which the available data span a relatively longer time period and are relatively reliable, although Turkey is by no means immune from the problems discussed above. Two empirical models of savings, Tansel (1992) and Celasun and Tansel (1993), can be reported. ${ }^{1}$ The former study estimated a simultaneous equations model for Turkey where the number of children is considered endogenous and the relationship between household saving, income, and the number of children are examined. The model is estimated utilizing the data from the results of household budget surveys in Ankara and Izmir. The results of Tansel (1992) indicate that in these two urban settings in Turkey children exert no significant influence on saving.

Celasun and Tansel (1993) presented econometric estimates for Turkish saving - investment behaviour over the 1972-1988 period. The estimation results capture the significant impact of functional income distribution on private as well as on total domestic saving. Financial liberalization appears to have produced a positive effect on private saving. Evidence points to the workings of a flexible accelerator mechanism for private capital formation under the strong influence of real import availability and unexpected inflation. The paper also provides estimated models for private saving surplus and current (external) account deficit. Real external deficit is found to be sensitive to shifts in domestic factor shares.

Motivated by the previous literature, this study investigates the effects on private saving rates of a number of policy and non-policy variables, including government policies, macroeconomic stability, income and financial variables as well as a number of life-cycle variables in Turkey. After a theoretical introduction to the possible determinants of savings and a description of the data, the empirical specifications and the results, as well as their relevance, are discussed. The analysis covers the period 1968-1994, and is largely based on data taken from the World Bank Savings Database (for the details of the data set see Loayza et al., 1998a, b). It is believed that this paper will be particularly useful since Turkey needs to create funds necessary for investment and to mobilize public and private savings for its speedy development.

The organization of the paper is as follows: Section II gives a brief explanation of the policy environment and saving behaviour in Turkey. Section III summarizes the potential determinants of private saving behaviour. In Section IV, the data is introduced and the empirical analysis is implemented. In Section V, the empirical specifications for the private savings are introduced and results are discussed. Finally, Section VI concludes.

\section{POLICY ENVIRONMENT AND SAVING BEHAVIOUR IN TURKEY}

An overview of the evolution of the Turkish economy might be helpful for analysing the saving behaviour in Turkey in the last three decades. In the post-1973 era, Turkey experienced a foreign-financed boom, and grappled with a severe debt crisis during the period 1978 - 1980. In early 1980, Turkey introduced liberalization of its product, financial and external markets. In the post-1980 period, export-oriented adjustments were observed. The post1989 populism caused unregulated financial liberalization during the 1989-1993 period. The 1994 crisis led to significant shifts in the macroeconomic characteristics of Turkey.

The 1978-1980 debt crisis fell mainly on investment rather than on saving, with aggregate saving rate falling from $20.9 \%$ to $17.3 \%$ (Metin Ozcan et al., 2001). The post-1980 reform caused a substantial rise in aggregate saving that served two main purposes in this period: to reduce inflation and to lower domestic absorption in order to make room for export expansion from the existing productive capabilities. During the post- 1980 period, the rise in aggregate saving was attained in its public saving component, notwithstanding the decline in private saving ratio in this period. As the annual growth rate of the Turkish economy increased after 1985, public saving began to worsen and private saving recovered. Public saving gap

\footnotetext{
${ }^{1}$ Among the other empirical studies Rittenberg (1988) investigated the financial liberalization and savings in Turkey and Kumcu (1989) analysed the savings behaviour of migrant workers: Turkish workers in Germany.
} 
and domestic inflation increased in this era. Turkey faced huge external debt service, which widened fiscal deficits. Moreover, domestic borrowing resulted in higher interest rates, and hence in larger volumes of interest payments by the public sector. As a result, public saving started to decline and private investment began to rise. The public saving gap had to be filled by a private saving surplus. Interest rate and domestic inflation became instrumental in boosting private saving (Celasun and Tansel, 1993). Furthermore, this situation began to worsen because of the unregulated financial liberalization in the post-1989 era; hence, as public saving continued to decline, private saving had an increasing trend (Kepenek and Yenturk, 1997, pp. 434-5). The 1994 crisis caused a significant shift in income distribution in Turkey. As real wages continued to decline, foreign capital inflows enabled the financing of the fiscal gap and the current account deficit. The cost of these adjustments to the treasury, however, was the acceleration of the interest burden on its borrowing instruments. The interest rate and inflation rose more than $30 \%$ in real terms. Therefore, aggregate saving rate especially, private saving rate, increased in 1994 (Metin Ozcan et al., 2001). As a result, we can say that Turkey had an increasing trend in aggregate saving rate after 1980 .

\section{POTENTIAL DETERMINANTS OF PRIVATE SAVINGS}

Both theoretical and empirical work on savings, have consistently outlined the major potential determinants of savings, which can be grouped loosely under the headings of government policy variables, financial variables, income and growth variables, demographic variables, financial variables, uncertainty measures, and external variables.

Although the main aim of this study is empirical modelling, it would not be correct to entirely bypass theoretical considerations, as the theory determines the choice of the variables to be used in the empirical specification. In this sense, this section will attempt to provide a flavour of the theoretical discussion on private savings, while touching upon the insights that previous empirical work has yielded.

The choice to save can be regarded basically as a consequence of intertemporal utility-maximization by rational agents, as saving is another name for consumption postponed. This insight constitutes the essence of the 'life-cycle approach' (Modigliani, 1970), which is the model most commonly referred to in studies of saving, notwithstanding the fact that no single model actually has the ability to account for every aspect of such a broad subject.
The major argument of the model is that individuals seek to smooth out consumption over time, saving in 'good times' to consume in 'bad times'. This precautionary motive for savings fundamentally affects the saving behaviour in the economy through a number of channels, which we discuss in detail in the following subsections, where a variety of policy and non-policy variables relevant to saving are outlined.

\section{Inertia}

It is an observed fact that saving rates generally contain inertia; that is, they are serially correlated, even after controlling for other factors. Hence, the lagged private saving rate should be included as a potential determinant of savings in a given year, which implies that factors that affect saving rates will have larger long-term impacts than shortterm ones.

\section{Government policies}

Various actions of government can have a bearing on saving. Among these, the effect of fiscal policy has especially been the centre of debate. Theoretical views on this relationship span a broad range. The neoclassical version of the life-cycle model asserts that a decline in government saving will tend to raise consumption and discourage saving by shifting the tax burden from present to future generations, and predicts that a decline in government saving will cause a decline in national saving. Empirical results reveal that government saving has crowded out private saving only partially. Therefore, raising government savings helps raise national saving (Dayal-Gulati and Thimann, 1997). On the other hand, the Keynesian model suggests that higher savings will result from a temporary reduction in public savings. Another view is the well-known Ricardian theory, which argues that an increase in government savings would have no effect on national saving, as it would be met by an equal decline in private saving. The term 'Ricardian Equivalence' refers to this full offsetting of the change in public savings by a change in private savings of equal magnitude and opposite sign. Previous empirical work has quite consistently found that the Ricardian Equivalence hypothesis does not hold rigidly, although some offsetting undoubtedly exists. ${ }^{2}$

Another act of government that can have a bearing on saving behaviour is the structure and extent of governmentrun social security programmes. Regarding this, the lifecycle model predicts that when the benefits to be received from the social security system are high, savings will tend to decline, primarily via the weakened motive for

${ }^{2}$ See Corbo and Schmidt-Hebbel (1991) for a detailed survey. 
retirement and precautionary savings (Evans, 1983). Also, Feldstein $(1980,1995)$ found a significant negative impact of pensions systems on private saving. Social security schemes were found in some cases to have a significant impact on private saving in studies of developing countries (Edwards, 1995).

\section{Income and growth variables}

The relationship between savings and income, on the other hand, the relationship between savings and growth have been a major subject of discussion in the growth literature. Subsistence-consumption theories suggest that countries with higher income levels tend to have a higher saving rate, and the empirical evidence strongly supports this conclusion (Edwards, 1996; Dayal-Ghulati and Thimann, 1997; Loayza et al., 1999; Metin-Ozcan and Ozcan, 2000).

Regarding income growth, however, the theoretical view is more blurred: the life-cycle approach suggests that the aggregate savings will increase in response to an increase in income growth, through an increase in the saving of active workers relative to the dissavings of people out of the labour force. Modigliani (1986) implies that faster growing countries should have a higher aggregate saving rate. Also, Collins (1989) found that income growth would increase savings. However, the permanent income hypothesis maintains that increased growth would imply higher anticipated future income, which would urge people to dissave against future earnings. In the face of these conflicting effects, it is left to empirical analysis to determine the actual outcome, and many studies have confirmed that there is indeed a 'virtuous circle' going from higher growth to higher savings and to even higher growth. But, there is also an endogeneity problem one should tackle while dealing with these issues: saving affects growth via its impact on investment and capital accumulation and in turn, growth affects savings through the above-mentioned channels. Nevertheless, in studies employing instrumental variable techniques and various causality tests to overcome the endogeneity problem, the 'virtuous circle' result has been maintained (Edwards, 1996).

\section{Financial variables}

The financial variables that have an impact on saving are usually ones that capture the degree of development of the financial sector. These variables are expected to be especially relevant for a developing country like Turkey, which has undergone - and still is undergoing - a liberalization process.

The most ambiguous financial variable that will be considered is the real interest rate. This is largely because of the fact that a change in the interest rate entails opposing substitution and income effects. Although the results of empirical studies have been no less ambiguous than the suggestions of theory regarding the impact of the interest rate, it is possible to state that the majority of the work has found only a weak interest elasticity of private saving (Boskin, 1978; Giovannini, 1983; McKinnon, 1991; Metin-Ozcan and Ozcan, 2000). This implies that the negative income effect of higher interest rates tends to neutralize their positive intertemporal substitution effect. For industrial countries, Koskela and Viren (1982) observed that savings increase as real rates of interest increase. In fact, Balassa (1992) argued that the effect of real interest rates on savings is positive for developing countries. Another relevant variable is the financial market development or 'financial depth', proxied by the degree of monetization of the economy, i.e. the M2/GNP ratio, where M2 represents money plus quasi-money. As expected, the sign of this variable has been found to be positive across empirical studies (Edwards, 1996; Dayal-Gulhati and Thimann, 1997; Loayza et al., 2000; Metin-Ozcan and Ozcan, 2000).

The third variable to be considered is the borrowing constraint which, if tight, can prevent people from borrowing extensively, thereby possibly inducing them to save for contingencies and for the purchases of houses, cars, etc. ${ }^{3}$ One would thus expect a relaxation of the borrowing constraint to have a negative impact on savings.

Apart from the effects discussed above, there is another channel through which financial liberalization may affect saving positively, which is the impact of a more efficient financial system on growth. Savings and growth are highly correlated in the long run, financial liberalization can indeed have an indirect long-run impact on savings through higher growth. In fact, Aron and Muellbauer 2000 show the importance of financial liberalization in private saving behaviour.

\section{Demographic variables}

The set of variables under the heading 'demographic variables' are usually the urbanization ratio, the age distribution of the population, and life expectancy. These variables are sometimes termed life-cycle variables, as they operate under the predictions of the life cycle and precautionary saving theories. In their seminal article, Ando and Modigliani (1963) show that demographic variables affect savings rates.

The age structure of the population is an important factor for savings because people, who seek to smooth out consumption over their lifetime, save when they expect future income to be low and dissave when they anticipate it to be high. According to this reasoning, young and old

\footnotetext{
${ }^{3}$ Akkoyunlu (1998) discussed thoroughly the effects of housing wealth on Turkish consumption and saving.
} 
people who are out of the labour force dissave, either against future earnings (as in the case of the young) or against previously accumulated savings (as in the case of the old). Economic agents will have negative savings when they are young and have very low income, positive savings during their productive years and negative savings when they are old and retired (Modigliani, 1970). Hence, the age distribution of the population affects private savings. When the share of the working population relative to that of retired persons increases, saving is likely to increase (Lahiri, 1989; Edwards, 1996; Dayal-Gulati and Thimann, 1997; Loayza et al., 2000).

Assuming that the bequest motive for saving is relatively small, the young and the old thus tend to have a low saving rate, whereas the highest saving rates are observed among people who are at or around the peak of their earnings. These findings have been captured in empirical work by employing two variables: the young and the old dependency ratios, where a decline in savings would be expected in response to an increase in either of these variables. It is these insights that have led many researchers to project (see, for instance, Masson et al., 1995) a downward trend in the saving rate in the near future, due to the ageing of the population, declining birth rates and increasing life expectancy.

Another demographic variable is the urbanization ratio, defined as the percentage of the total population living in urban areas. This variable is also expected to have a negative impact on saving, as increased urbanization reduces the need for precautionary saving, which is high in rural societies with greater volatility in income. In the empirical work, the signs of the demographic variables have usually been found negative. However, as in the case of many other variables, the empirical significance varies a lot across studies.

\section{Uncertainty variables}

The variables that capture the effects of uncertainty about the future bear on saving rates primarily via their impact on precautionary savings. These variables can be termed broadly as macroeconomic stability and political stability.

Macroeconomic uncertainty, usually proxied by the inflation rate, is expected to have a positive impact on saving, as people in such an environment would try to hedge risk by saving. For a group of industrial countries, Koskela and Viren (1985) reported that savings increase as the inflation rate increase. Also, Gupta (1987) found that both expected and unexpected components of inflation had a positive effect on savings for a group of Asian countries.

In the same sense, political instability, which creates an uncertain economic environment for agents, would be expected to act positively on savings. It is also possible to consider uncertainty at the individual level by the extent and coverage of government-run social security and insurance programmes and/or the urbanization ratio - implying decreased volatility of income - which had been discussed under different headings. This indicates that the categorization of variables made here is by no means strict, and that a variable can be categorized under multiple headings because of its dual - or at times triple - nature.

\section{External variables}

The external variables that might be relevant to savings are the terms of trade and the current account deficit. For an open economy model, terms of trade is a critical variable, particularly for oil exporters (Ostry and Reinhart, 1992; Dayal-Gulati and Thimann, 1997; Loayza et al., 2000). Positive terms of trade shocks increase saving through the positive effect on wealth and income (Fry, 1986, Masson et al., 1995). The standard view on the latter is that an increase in external saving or the current account deficit is met by a partial decline in private saving, as external saving may tend to act as a substitute to domestic private saving (Loayza et al., 2000).

\section{DATA AND EMPIRICAL ANALYSIS}

\section{Data}

Our analysis of the private and public saving rates is based largely on the World Saving Database (WSD), which is the largest data set on aggregate saving measures assembled to date (see Loayza et al., 1998a for a detailed description of the WSD).

The database consists of five modules, with the modules described briefly as follows:

Module 1: Gross National Savings, Gross National Disposable Income and other national accounts aggregates. Module 2: Unadjusted and adjusted (for inflation and exchange rate depreciation related capital gains) private and public saving rates which correspond to the consolidated central government (CCG) definition of public savings.

Module 3: Unadjusted and adjusted (for inflation and exchange rate depreciation related capital gains) private and public saving rates which correspond to an extended definition of the public sector, either as the general government or as the consolidated non-financial public sector.

Module 4: Data on variables considered as the major savings determinants, grouped as financial variables, family and demographic structure variables, poverty and inequality variables, social security and external variables. Module 5: Data on saving and investment disaggregated at a household, firm and general government level, for a limited number of countries.

Despite the breadth of the database, it should be noted that the data availability of a variable can differ 
substantially across countries, and - more crucially for this study - so can the time coverage of the variables for a specific country. As mentioned in the introduction, Turkey is by no means immune from imperfections in the data, and in this study, which covers the period 1968 1994, these imperfections have prevented it from using the government's social security expenditures, the spread between average deposit and lending rates, and the T-bill rate or money market rates (which would probably improve the explanatory power) in the empirical specification, so as not to shrink the time coverage of the study substantially.

To be able to correct for some of these deficiencies in the data, two interest rate variables have been taken, 'interest rate on savings deposits' and the 'discount rate', rom the database of the Turkish State Planning Organization (SPO). ${ }^{4}$

The inflation rate has been computed as the annual change in the natural logarithm of the GNP deflator. In addition, two dummy variables have been constructed, one to represent political instability and the other to capture the effects of Turkish crisis years on the private saving rate. The political instability variable, POLINS, is a dummy that takes on the value of 0 if there has been no government transfer in a given year, 1 if there has been one government change, and 2 if there has been more than one transfer. The crisis dummy, DUMMY, on the other hand, takes on the value of 1 in the years of economic crisis and zero otherwise.

The study uses the gross private disposable income (GPDI) as the basic income measure in the analysis of private savings, which is computed as gross private savings, which is gross national savings minus the relevant definition of public savings plus private consumption both measured at current prices. In line with the description of the modules given earlier, the analysis of private saving rates is based on a total of four alternative samples. These are the unadjusted and adjusted private saving rates corresponding to the CCG definition of the public sector (CU and CA), as well as the unadjusted and adjusted private saving rates corresponding to the broad public sector definition of public savings ( $\mathrm{PU}$ and $\mathrm{PA}$ ). This distinction is especially important for a country like Turkey, where the public enterprise sector is quite large. The CCG definition, by construction, lumps local government and public enterprises together with the private sector, whereas the broad public sector corresponds to the consolidated non-financial public sector in Turkey. Of the four alternative measures cited above, the analytically preferable one is clearly the adjusted saving rate corresponding to the broad public sector definition (Loayza et al., 1999), especially for a coun- try like Turkey where the inflation rate is high, the exchange rate is volatile and the public enterprise sector is large. Nevertheless, all the samples will be analysed with the prospect of gaining greater insight into the determinants of saving rates.

\section{Unit root tests}

The Augmented Dickey - Fuller (ADF) (1981) tests are applied to study the unit roots in the variables. For a given variable and null order, two values are reported in each cell. The first value is the ADF statistics and the second value in the parentheses is the longest significant lag with significant $t$-value. Four lags are allowed in each variable's ADF regression. All regression include constant term. ' $a$ ' denotes time trend and ' $b$ ' denotes time trend is not included. If variables are in their log levels, the sample is $1968-1994(t=27)$. If the variables are in their first differences the sample is 1969-1994 $(t=26)$. The ADF tests suggest that regarding four alternative definitions of the public sector CU, CA, PA, PU all variables seem to be $I(0)$ except $C A-G S, C A-U R, C A-L E X, P U-G S$ and $P A-$ $G S$ which are $I(1)$. The ADF test results are reported in Table 1.

\section{EMPIRICAL SPECIFICATION FOR PRIVATE SAVINGS}

In line with the potential savings determinants outlined in Section III, the general private saving equation including all relevant variables is constructed as follows:

$$
\begin{aligned}
S_{t}= & \beta_{0} S_{t-1}+\beta_{1} M 2_{t}+\beta_{2} C R_{t}+\beta_{3} I N F_{t}+\beta_{4} G S_{t} \\
& +\beta_{5} L Y_{t}+\beta_{6} D L Y_{t}+\beta_{7} Y D_{t}+\beta_{8} O D_{t}+\beta_{9} U R_{t} \\
& +\beta_{10} L E X_{t}+\beta_{11} R E A L T D_{t}+\beta_{12} \text { POLINS }_{t}+\beta_{13} C A D_{t} \\
& +\beta_{14} T T_{t}+\beta_{15} D U M M Y_{t}
\end{aligned}
$$

In this setting, the subscript ' $t$ ' denotes time, whereas $L$ denotes the logarithm of the relevant variable. The dependent variable for the private saving equation is $S$, which represents the private saving rate, defined as the gross private disposable income (both corresponding to the relevant definition of the public sector).

Among the regressors, $S_{t-1}$ denotes the lagged dependent variable, $G S$ is the relevant public sector saving to GDPI ratio, $M 2$ indicates the ratio of money plus quasi-money to GNP, REALTD is the real interest rate on savings deposits, $C R$ denotes credit to the private sector (end of period), expressed as a percentage of GDPI.

\footnotetext{
${ }^{4}$ These nominal rates were converted into real ones through the well-known Fisher equation: $1+r_{t}=\left(1+i_{t}\right) /\left(1+\Pi_{t}^{e}\right)$, where $\Pi_{t}^{e}$ denotes expected inflation, $r_{t}$ the real and $i_{t}$ the nominal interest rate.
} 
Table 1. Augmented Dickey-Fuller (ADF) test statistics

\begin{tabular}{|c|c|c|}
\hline Variable & $\begin{array}{c}\text { Null order } \\
I(0)\end{array}$ & $\begin{array}{l}\text { Null order } \\
I(1)\end{array}$ \\
\hline$C A-S$ & $-5.13(0)^{*, \mathrm{a}}$ & \\
\hline$C A-M 2$ & $-4.18(0)^{*, \mathrm{~b}}$ & \\
\hline$C A-C R$ & $-4.05(1)^{*, \mathrm{~b}}$ & \\
\hline$C A-I N F$ & $-4.21(1)^{* *, a}$ & \\
\hline$C A-G S$ & $-2.47(0)^{\mathrm{b}}$ & $-4.65(1)^{*, \mathrm{~b}}$ \\
\hline$C A-L Y$ & $-3.62(0)^{* *, \mathrm{~b}}$ & \\
\hline$C A-Y D$ & $-6.28(0)^{*, \mathrm{~b}}$ & \\
\hline$C A-O D$ & $-4.78(0)^{*, \mathrm{~b}}$ & \\
\hline$C A-U R$ & $-1.55(4)^{\mathrm{a}}$ & $-8.25(3)^{*, \mathrm{~b}}$ \\
\hline$C A-L E X$ & $-2.26(0)^{\mathrm{b}}$ & $-4.16(0)^{*, \mathrm{~b}}$ \\
\hline$C A-R E A L T D$ & $-4.91(1)^{*, \mathrm{a}}$ & \\
\hline CA-POLINS & $-5.46(0)^{*, \mathrm{~b}}$ & \\
\hline$C A-C A D$ & $-2.94(0)^{* *, \mathrm{~b}}$ & \\
\hline$C A-T T$ & $-4.6(0)^{*, \mathrm{~b}}$ & \\
\hline$C U-S$ & $-4.51(0)^{*, \mathrm{a}}$ & \\
\hline$C U-C R$ & $-4.34(0)^{*, \mathrm{a}}$ & \\
\hline$C U-G S$ & $-4.13(1)^{*, \mathrm{a}}$ & \\
\hline$C U-L Y$ & $-6.23(0)^{*, \mathrm{~b}}$ & \\
\hline$C U-C A D$ & $-4.30(0)^{*, \mathrm{a}}$ & \\
\hline$P U-S$ & $-3.41(0)^{* * *, \mathrm{a}}$ & \\
\hline$P U-C R$ & $-4.13(0)^{*, \mathrm{~b}}$ & \\
\hline$P U-G S$ & $-0.63(0)^{\mathrm{b}}$ & $-4.68(0)^{*, \mathrm{~b}}$ \\
\hline$P U-L Y$ & $-3.51(0)^{* *, \mathrm{~b}}$ & \\
\hline$P U-C A D$ & $-3.54(0)^{* *, a}$ & \\
\hline$P A-S$ & $-4.00(0)^{*, \mathrm{~b}}$ & \\
\hline$P A-C R$ & $-3.20(1)^{* *, \mathrm{~b}}$ & \\
\hline$P A-G S$ & $-1.94(0)^{\mathrm{b}}$ & $-4.40(0)^{* *, \mathrm{~b}}$ \\
\hline$P A-L Y$ & $-5.44(0)^{*, \mathrm{~b}}$ & \\
\hline$P A-C A D$ & $-3.33(3) * * *, \mathrm{a}$ & \\
\hline
\end{tabular}

Note: The critical values are from MacKinnon (1991, Table 1). Here and elsewhere in this article, *,** and *** denote rejection at the $1 \%, 5 \%$ and $10 \%$ level critical values respectively.

Among the demographic/life-cycle variables, $Y D$ and $O D$ are age dependency ratios, the former expressing the young dependency ratio, defined as the ratio of the population younger than 15 to the total population, and the latter the old dependency ratio, defined as the ratio of the population older than 65 to the total population. $U R$, on the other hand, is the urbanization ratio, which expresses the percentage of the population living in urban areas, and $L E X$ denotes life expectancy at birth.

$T T$ stands for the terms of trade, defined as the ratio of nominal exports/imports to real exports/imports. $C A D$ represents the current account deficit ratio, calculated as the difference between imports and exports over GPDI. $L Y$ and $D L Y$ are income and growth variables respectively, the former representing the level and the latter the growth rate of real per capita GPDI. INF is the inflation rate, measured by the annual change in the logarithm of the GNP deflator.
POLINS is the political instability variable and DUMMY the dummy variable for crisis years.

\section{Estimation results for the private saving rate}

The OLS estimation results of the full model, in which we have included all potential savings determinants as well as a dummy variable capturing the years of economic crisis in Turkey (1980 and 1994), are presented in Table 2 for the four alternative definitions of the public sectors.

One of the most prominent insights that emerge from these estimations is that the coefficient for the crisis dummy is negative and statistically significant in all four samples. Moreover, the inclusion of the dummy provides a major improvement in the empirical significance of other savings determinants, whereas no variable appears to be statistically significant in case of the exclusion of the dummy in any sample. ${ }^{5}$

Alternatively, the three demographic variables (young dependency, old dependency and the urbanization ratio) are excluded, $C R, D L Y$ and $C A D$ variables are excluded, which are uniformly insignificant across samples, one gets the results given in Table 3. When the two basic private savings estimation results presented above are analysed, one can gain some insight into the determination of private saving rates in Turkey, and into whether they fit the theoretical predictions that were discussed earlier.

\section{Inertia}

The presence of inertia in private saving rates in Turkey is clearly evident from the empirical results given in Tables 2 and 3 , as the coefficient of the lagged private saving rate is uniformly positive across all samples and statistically significant in three out the four samples, insignificant in only the adjusted private saving sample corresponding to the broad public sector definition (PA). The coefficient of the lagged saving rate ranges from 0.63 to 0.72 , implying that the factors that affect the private saving rate have a 2.68 to 3.55 times larger longer-term impact than their short-term impact. This result is consistent with the findings of the previous research (Loayza et al., 1999).

\section{Government policies}

Yet another striking result that emerges from the analysis is that the coefficient for the public saving rate $(G S)$ in the full model, lending no support to the 'crowding out' hypothesis. However, in Table 3, where the insignificant demo-

\footnotetext{
${ }^{5}$ To save the space results are not provided here.
} 
Table 2. Estimation results

\begin{tabular}{|c|c|c|c|c|}
\hline \multicolumn{5}{|c|}{ Estimation results of the full private saving model } \\
\hline Private sector definition & $\mathrm{CU}$ & $\mathrm{CA}$ & PU & PA \\
\hline \multirow[t]{2}{*}{$\overline{S(-1)}$} & $0.627 * * *$ & $0.619 * * *$ & $0.718 * * *$ & 0.446 \\
\hline & $(2.939)$ & $(2.153)$ & $(2.319)$ & $(1.366)$ \\
\hline \multirow{2}{*}{$M 2$} & $1.085^{* * *}$ & $1.036^{* * *}$ & $1.147 * * *$ & $1.879 * * *$ \\
\hline & $(2.241)$ & $(1.892)$ & $(1.879)$ & $(2.533)$ \\
\hline \multirow[t]{2}{*}{$C R$} & 0.561 & 0.611 & -0.282 & 0.181 \\
\hline & $(1.003)$ & $(0.879)$ & $(-0.273)$ & $(0.159)$ \\
\hline \multirow[t]{2}{*}{$I N F$} & $0.394 * * *$ & 0.408 & 0.235 & 0.469 \\
\hline & $(2.046)$ & $(1.706)$ & $(0.769)$ & $(1.513)$ \\
\hline \multirow[t]{2}{*}{$G S$} & 0.014 & 0.074 & -0.165 & 0.118 \\
\hline & $(0.035)$ & $(0.127)$ & $(-0.284)$ & $(-0.192)$ \\
\hline \multirow[t]{2}{*}{$L Y$} & 0.047 & 0.082 & 0.082 & -0.189 \\
\hline & $(0.403)$ & $(0.535)$ & $(0.293)$ & $(-0.552)$ \\
\hline \multirow[t]{2}{*}{$D L Y$} & 0.160 & 0.129 & -0.008 & 0.135 \\
\hline & (1.019) & $(0.718)$ & $(-0.026)$ & $(0.425)$ \\
\hline \multirow[t]{2}{*}{$Y D$} & -0.087 & -0.906 & -0.967 & 6.572 \\
\hline & $(-0.027)$ & $(-0.215)$ & $(-0.138)$ & $(0.735)$ \\
\hline \multirow[t]{2}{*}{$O D$} & 5.489 & 4.413 & 4.880 & 1.837 \\
\hline & $(0.861)$ & $(0.521)$ & $(0.514)$ & $(0.220)$ \\
\hline \multirow[t]{2}{*}{$U R$} & 0.033 & -0.330 & -0.362 & 1.864 \\
\hline & $(0.039)$ & $(-0.300)$ & $(-0.170)$ & $(0.695)$ \\
\hline \multirow[t]{2}{*}{$L E X$} & $-0.025^{* * *}$ & $-0.024 * * *$ & $-0.019 * * *$ & $-0.025^{* * * *}$ \\
\hline & $(-2.973)$ & $(-2.809)$ & $(-1.842)$ & $(-2.222)$ \\
\hline \multirow[t]{2}{*}{ REALTD } & -0.001 & 0.015 & 0.058 & 0.217 \\
\hline & $(-0.005)$ & $(0.122)$ & $(0.383)$ & (1.049) \\
\hline \multirow[t]{2}{*}{ POLINS } & -0.009 & -0.009 & -0.011 & -0.018 \\
\hline & $(-1.413)$ & $(-1.099)$ & $(-1.157)$ & $(-1.885)$ \\
\hline \multirow[t]{2}{*}{$C A D$} & 0.364 & 0.446 & 0.617 & 1.417 \\
\hline & $(0.483)$ & $(0.749)$ & $(0.948)$ & $(1.348)$ \\
\hline \multirow[t]{2}{*}{$T T$} & $0.255^{* * *}$ & $0.235^{* * *}$ & 0.117 & 0.109 \\
\hline & $(3.619)$ & $(2.769)$ & $(1.281)$ & $(1.046)$ \\
\hline \multirow[t]{2}{*}{$D U M M Y$} & $-0.115^{* * *}$ & $-0.113 * * *$ & $-0.100 * * *$ & $-0.086^{* * *}$ \\
\hline & $(-4.189)$ & $(-3.482)$ & $(-2.607)$ & $(-2.007)$ \\
\hline$R^{2}$ & 0.969 & 0.943 & 0.926 & 0.927 \\
\hline
\end{tabular}

Notes: $t$-statistics in parentheses.

$(*),(* *)$ and $(* * *)$ indicates statistical significance at $1 \%, 5 \%$ and $10 \%$ level, respectively.

graphic, $C R, D L Y$ as well as $C A D$ variables are excluded, it is found that the $G S$ becomes significantly negative in the samples corresponding to the broad definition of the public sector (PA and PU). Moreover, the coefficient of public savings is larger in absolute value in the broad public sector samples. This observation may be due to the fact that the distinction between private and public savings is analytically more correctly defined in the case of the broad public sector definition, especially for a country like Turkey, for reasons discussed earlier.

\section{Income and growth variables}

This analysis reveals that, in the full regression where all the variables are included, the level of income is insignificant, with differing signs across samples. However, once the insignificant demographic, $C R, D L Y$ and $C A D$ vari- ables are excluded from the equation, the coefficient of the level of income becomes positive and statistically significant in the samples corresponding to the broad definition of the public sector (PA and PU). The magnitude of its coefficient ranges from 0.05 to 0.06 , indicating that a $1 \%$ increase in per capita real GPDI will have a 5 to $6 \%$ increase in the private saving rate.

However, the picture is much worse regarding income growth, and does not improve when the insignificant variables are excluded. Namely, the growth rate of income is insignificant everywhere it is included - even in smaller regressions that have been run - and with differing signs of its coefficient. This indicates that the 'virtuous circle' prediction discussed earlier does not seem to hold for Turkey, possibly because of the lack of a sustained and stable phenomenon of growth in the economy. 
Table 3. Estimation results

\begin{tabular}{|c|c|c|c|c|}
\hline Private sector definition & $\mathrm{CU}$ & $\mathrm{CA}$ & PU & PA \\
\hline \multicolumn{5}{|c|}{ Estimation results of the private saving model without demographic, $C R, D L Y$ and $C A D$ variables } \\
\hline \multirow[t]{2}{*}{$S(-1)$} & $0.535^{* * *}$ & $0.591 * * *$ & $0.643^{* * *}$ & $0.493 * * *$ \\
\hline & $(4.081)$ & $(4.495)$ & $(4.016)$ & $(2.908)$ \\
\hline \multirow[t]{2}{*}{$M 2$} & $0.664 * * *$ & $0.636 * * *$ & $0.621 * * *$ & $1.011 * * *$ \\
\hline & $(2.754)$ & $(2.915)$ & $(2.412)$ & $(3.069)$ \\
\hline \multirow[t]{2}{*}{$I N F$} & $0.153 * * *$ & $0.142 * * *$ & $0.160 * * *$ & $0.195 * * *$ \\
\hline & $(2.232)$ & $(2.464)$ & $(2.570)$ & $(2.673)$ \\
\hline \multirow[t]{2}{*}{$G S$} & -0.305 & -0.285 & $-0.421 * * *$ & $-0.656^{* * *}$ \\
\hline & $(-1.455)$ & $(-1.389)$ & $(-2.229)$ & $(-2.951)$ \\
\hline \multirow[t]{2}{*}{$L Y$} & 0.028 & 0.034 & $0.049 * * *$ & $0.061 * * *$ \\
\hline & (1.103) & $(1.736)$ & (1.979) & $(2.303)$ \\
\hline \multirow[t]{2}{*}{$L E X$} & $-0.011^{* * *}$ & $-0.012 * * *$ & $-0.014 * * *$ & $-0.018 * * *$ \\
\hline & $(-1.827)$ & $(-2.543)$ & $(-2.422)$ & $(-2.778)$ \\
\hline \multirow[t]{2}{*}{$R E A L T D$} & -0.033 & -0.044 & 0.012 & -0.008 \\
\hline & $(-0.398)$ & $(-0.589)$ & $(0.151)$ & $(-0.077)$ \\
\hline \multirow[t]{2}{*}{ POLINS } & -0.001 & -0.008 & -0.010 & $-0.014 * * *$ \\
\hline & $(-0.067)$ & $(-1.609)$ & $(-1.592)$ & $(-1.936)$ \\
\hline \multirow[t]{2}{*}{$T T$} & $0.179 * * *$ & $0.172 * * *$ & $0.121 * * *$ & 0.101 \\
\hline & $(2.962)$ & $(3.125)$ & $(2.028)$ & (1.497) \\
\hline \multirow[t]{2}{*}{$D U M M Y$} & $-0.078 * * *$ & $-0.075^{* * *}$ & $-0.076^{* * *}$ & $-0.049 * * *$ \\
\hline & $(-3.739)$ & $(-3.804)$ & $(-3.731)$ & $(-2.094)$ \\
\hline$R^{2}$ & 0.935 & 0.917 & 0.909 & 0.904 \\
\hline \multicolumn{5}{|c|}{ Estimation results of the private saving model with financial variables as a group with $S(-1)$ and dummy } \\
\hline \multirow{2}{*}{$S(-1)$} & $0.506^{* * *}$ & $0.453 * * *$ & $0.672 * * *$ & $0.569 * * *$ \\
\hline & $(3.725)$ & $(3.017)$ & $(5.328)$ & $(3.832)$ \\
\hline \multirow[t]{2}{*}{$M 2$} & $0.849 * * *$ & $0.797 * * *$ & $0.637 * * *$ & $0.731 * * *$ \\
\hline & $(3.762)$ & $(3.446)$ & $(3.304)$ & $(3.342)$ \\
\hline \multirow[t]{2}{*}{$C R$} & $-0.484 * * *$ & -0.374 & $-0.439 * * *$ & $-0.526^{* * *}$ \\
\hline & $(-2.249)$ & $(-1.660)$ & $(-2.367)$ & $(-2.345)$ \\
\hline \multirow[t]{2}{*}{ REALTD } & -0.033 & -0.051 & -0.027 & 0.004 \\
\hline & $(-0.719)$ & $(-1.109)$ & $(-0.688)$ & $(0.071)$ \\
\hline \multirow[t]{2}{*}{$D U M M Y$} & $-0.051 * * *$ & $-0.055 * * *$ & $-0.047 * * *$ & -0.024 \\
\hline & $(-2.503)$ & $(-2.696)$ & $(-2.629)$ & $(-1.049)$ \\
\hline$R^{2}$ & 0.841 & 0.769 & 0.852 & 0.818 \\
\hline
\end{tabular}

Notes: $t$-statistics in parantheses.

$(*),(* *)$ and $(* * *)$ indicates statistical significance at $1 \%, 5 \%$ and $10 \%$ level, respectively.

\section{Financial variables}

The results regarding financial variables clearly show that, in any sample, with or without the insignificant variables, the money to GNP ratio is positive and statistically significant. This finding confirms the prediction that an increase in 'financial depth', proxied by the increase in the M2/GNP ratio, is likely to be very important in a country like Turkey, which is undergoing a financial liberalization process.

However, it was found out that the real interest rate (on saving deposits) is insignificant with changing signs of its coefficient across samples, and so is the credit to the private sector. The former finding fits the results of many previous empirical studies mentioned earlier, which have found an insignificant impact of the real interest rate. However, when separate regressions were run solely for the financial variables as a group, along with the lagged private saving rate and the dummy, it is seen that the 'credit to the private sector/gross private disposable income' takes on a significantly negative coefficient reflecting the borrowing constraint. This suggests that the relaxation of credit constraints leads to a decrease in the private saving rate (Japelli and Pagano, 1995; Loayza et al., 2000). Another point that deserves attention is that, according to the estimation results, private saving model with financial variables, the financial variables are usually able to explain 43 to $85 \%$ of the variation in private saving rates in Turkey (Table 3).

\section{Demographic variables}

Another striking result that emerges from the analysis is that three of the demographic variables $(Y D, O D, U R)$ are insignificant in the full sample, and $Y D$ and $U R$ have signs 
that are not robust across samples. This may be due to the fact that, in a developing country like Turkey, where the family structure is still quite traditional, the age dependency ratios are likely to exhibit a picture divergent from the predictions of pure theory. The most vivid example, probably, is the devotion of a great part of the household's resources to child rearing, until the children start to earn their own income, no matter when. This increases the burden of the adults, lessening their chance to save (MetinOzcan and Ozcan, 2000). This observation, coupled with the fact that it is seen as the children's responsibility to care for the old, brings forth the possibility that the old can be expected to save more, along with the lowered expenses in their budget.

The coefficient of the life-cycle variable 'life expectancy', on the other hand, is negative and statistically significant in every estimation and for every sample, indicating that a $1 \%$ increase in life expectancy lowers the private saving rate by about $2 \%$, through the ageing of the population and the reduction in the working-age population. This result is in line with the predictions of the life cycle and precautionary saving models.

\section{Uncertainty variables}

The estimation results show that, although inflation has a positive coefficient in every regression, its coefficient is statistically significant in the full model only for the unadjusted CCG (CU) sample. However, when the insignificant variables are excluded from the empirical specification, the coefficient for the inflation rate becomes significantly positive for all samples (Table 3). According to Table 3 results, inflation is able to explain 14 to $20 \%$ of variation in private saving rates in Turkey.

\section{External variables}

Among the external variables, it is seen that the terms of trade $(T T)$ is significant in the full model only for the samples corresponding to the CCG definition of the public sector (CA and $\mathrm{CU})$. In the regressions where the insignificant variables are excluded, $T T$ is again significant for the CCG and PU samples. The findings indicate that terms of trade shocks positively affect the private saving rate in Turkey. Hence, the results support the Ostry and Reinhart (1992) findings.

The current account deficit $(C A D)$, however, is not statistically significant in any of the regressions. This may be attributed to the nature of the current account deficit as an explanatory variable, as it is usually considered a 'dubious regressor', for it is 'jointly determined with saving in countries and/or at time periods characterized by unrestricted access to foreign lending, and is exogenously determined otherwise' (Loayza et al., 2000, p. 16).

\section{CONCLUSIONS}

This paper examines the empirical determinants of private saving for Turkey. Factors that account for saving can be summarized as follows. In Turkey private saving rates have strong inertia and they are highly serially correlated. The effects of a change in a given saving determinant are fully realized in the long term rather than in the short term (less than a year).

Another finding of this study is that government savings to GPDI ratio has a negative impact on the saving rate, confirming the claim that government savings will tend to crowd out private savings. For Turkey, an increase in government savings is offset by a reduction in public savings. The findings further indicate that, although higher government savings crowd out private savings, they do it in a less than one-to-one manner, and thus the Ricardian equivalence does not hold strictly.

Income level has a positive impact on the private saving rate for Turkey. This finding is consistent with the empirical results of cross-country studies, which indicate, ceteris paribus, that more advanced countries tend to save a higher percentage of their GDP. Growth rate of income is not statistically significant, which does not support the hypothesis that there is a virtuous circle that goes from faster growth to increased saving to even higher growth. Moreover, the negative impact of life expectancy rate on lends support to the life-cycle hypothesis.

From a policy point of view, the financial depth and development measure suggests that countries with deeper financial systems will tend to have higher private saving rates, which is consistent with the findings of this study. Turkish private credit and real interest rates try to capture the severity of the borrowing constraints and the degree of financial repression. The precautionary motive for saving is supported by the findings that inflation captures the degree of macroeconomic volatility and has a positive impact on private saving in Turkey.

Furthermore, it is important to investigate whether external factors influence private saving or not for Turkey since Turkey has an open economy. The first potential external factor influencing private saving is the terms of trade. It is found that terms of trade shocks increase private saving in Turkey. Also, the current account deficit is an important explanatory variable for the private savings, but its effect is insignificant in Turkey. Moreover, it can be said that the Turkish economic crisis has significantly negative effects on saving behaviour.

The empirical findings presented here indicate a number of variables that affect private savings in Turkey. The complexity of the relationship between saving and other variables are examined. These variables clearly indicate the role of policies pursued by the country that affect saving. According to the empirical findings, it can be said that financial market development, 
macroeconomic stability, life expectancy, external factors and economic crisis may be the core policy instruments in Turkey for the saving behaviour.

\section{REFERENCES}

Akkoyunlu, S. (1998) Turkish consumption and saving. University of Oxford, St Antony's College, $\mathrm{PhD}$ thesis.

Ando, A. and Modigliani, F. (1963) The life cycle hypothesis of saving aggregate implications and tests, American Economic Review, 53, 55-84.

Aron, J. and Muellbauer, J. (2000) Personal and corporate saving in South Africa, World Bank Economic Review, 14, 509-44.

Balassa, B. (1992) The effects of interest rates on saving in developing countries, Banca Nazionale del Lavoro Quarterly Review, 172. pp

Boskin, M. (1978) Taxation, savings and the rate of interest, Journal of Political Economy, 86, S3-S28.

Celasun, M. and Tansel, A. (1993) Distributional effects and saving-investment behaviour in liberalizing economy: the case of Turkey, Middle East Technical University Studies in Development, 20, 269-98.

Collins, S. M. (1989) Saving behaviour in ten developing countries. Paper presented at the NBER Conference on Savings, Maui. National Bureau of Economic Research, Cambridge, MA.

Corbo, V. and Schmidt-Hebbel, K. (1991) Public policies and saving in developing countries, Journal of Development Economics, 36, 89-115.

Dayal-Ghulati, A. and Thimann, C. (1997) Saving in Southeast Asia and Latin America compared: searching for policy lessons. IMF Working Paper WP/97/110.

Edwards, S. (1996) Why are Latin America's savings rates so low? An international comparative analysis, Journal of Development Economics, 51, 5-44.

Edwards, S. (1995) Why are saving rates so different across countries? An international comparative analysis. NBER Working Paper, 5097.

Evans, O. (1983) Social security and household saving in the United States: a re-Examination, Staff Papers, International Monetary Fund, 30, 601-18.

Feldstein, M. (1980) International differences in social security and saving, Journal of Public Economies, 14, 225-44.

Feldstein, M. (1995) Social security and saving new time series evidence. NBER Working Paper 5054.

Friedman, M. (1957) A Theory of the Consumption Function, Princeton University Press for the National Bureau of Economic Research, Princeton, NJ.

Fry, M. (1986) Terms-of-trade dynamics in Asia: an analysis of national saving and domestic investment, Journal of International Money and Finance, 5, 57-73.

Giovannini, A. (1983) The interest elasticity of savings in developing countries: the existing evidence. World Bank, 11 (July).

Gupta, K. L. (1970a) Foreign capital and domestic savings: a test of Haavelmo's hypothesis with cross-country data: a comment, Review of Economics and Statistics, 52, 214-16.

Gupta, K. L. (1970b) On some determinants of rural and urban household saving behaviour, Economic Record, 46, 578-83.

Gupta, K. L. (1971) Dependency rates and savings rates: comment, American Economic Review, 61, 469-71.

Gupta, K. L. (1987) Aggregate savings, financial intermediation, and interest rate, Review of Economics and Statistics, 69, 303-11.
Japelli, T. and M. Pagano (1995) Saving, growth and liquidity constraints, Quarterly Journal of Economics, 109, 83-109.

Kelley, A. and Williamson, J. (1968) Household saving behaviour in the developing economies: the Indonesian case, Economic Development and Cultural Change, 16(3).

Kepenek, Y. and Yenturk, N. (1997) Türkiye Ekonomisi, Remzi Kitabevi Yayinlari, Dokuzuncu Basim.

Koskela, E. and Viren, M. (1982) Saving and inflation: some international evidence, Economics Letters, 9(4). pp

Koskela, E. and Viren, M. (1985) Anticipated versus 'surprise' inflation in household consumption behaviour, Economics Letters, 17(1-2). pp

Kumcu, M. E. (1989) The savings behaviour of migrant workers: Turkish workers in W. Germany, Journal of DevelopmentEconomics, 30, 273-86.

Lahiri, A (1989) Dynamics of Asian saving, Staff Papers, International Monetary Fund, 36, 228-61.

Leff, N. H. (1969) Dependency rates and savings rates, American Economic Review, 59, 886-96.

Leff, N. H. (1971) Dependency rates and saving rates: reply, American Economic Review, 61, 476-80.

Loayza, N., Lopez, H., Schmidt-Hebbel, K. and Serven, L. (1998a) The World Saving Database. World Bank Manuscript, The World Bank, Washington, DC.

Loayza, N., Lopez, H., Schmidt-Hebbel, K. and Serven, L. (1998b) Saving in the World: facts, trends, correlations. Manuscript presented at the World Bank Conference on Saving in the World: Puzzles and Policies, The World Bank, Washington, DC, Sept. 16-18.

Loayza, N., Schmidt-Hebbel, K. and Serven, L. (2000) What drives private savings across the World. The Review of Economics and Statistics, May, 165-81.

Masson, P., Bayoumi, T. and Samiei, H (1995) International evidence on the determinants of private saving. IMF Working Paper 95/51.

MacKinnon, J. G. (1991) Critical values for the cointegration tests, in Long Run Ecoonomic Relationsips (Eds) R. F. Engle and C. W. J. Granger, Oxford University Press, Oxford, pp. $267-76$

McKinnon, R. (1991) The Order of Economic Liberalization: Financial Control in the Transition to a Market Economy, Johns Hopkins University Press, Baltimore.

Metin Ozcan, K. and Ozcan, Y. Z. (2000) Determinants of private saving in MENA region, Iran and Turkey, Proceedings of the MDF website at htttp://www.worldbank.org/mdf, forthcoming in Research in Middle East Economies.

Metin Ozcan, K., Voyvoda, E. and Yeldan, A., E. (2001) Dynamics of macroeconomic adjustment in a globalized developing economy: growth, accumulation and distribution, Turkey 19691999, Canadian Journal of Development Studies, 22, 219-53.

Modigliani, F. (1970) The life cycle hypothesis of saving and inter country differences in the saving ratio, in Induction, Growth and Trade (Eds) W. Eltis, M. Scott and J. Wolfe, Oxford University Press, Oxford.

Modigliani, F. (1986) Life cycle, individual thrift, and the wealth of nations, American Economic Review, 76, 297-313.

Muradoglu, G. and Taskin, F. (1996) Differences in household savings behaviour: evidence from industrial and developing countries, The Developing Economies, 34, 138-153.

Ortmeyer, D. L. (1985) A portfolio model of Korean household saving behaviour, 1962-1976, Economic Development and Cultural Change, 33, 575-99.

Ostry, J. and Reinhart, C. (1992) Private saving and terms-of trade shocks: evidence from developing countries, Staff Papers, International Monetary Fund, 39, 495-517. 
Ouliaris, S. (1981) Household saving and the rate of interest, Economic Record, 57, 205-14.

Rittenberg, L. (1988) Financial liberalization and savings in Turkey, in Liberalization and the Turkish economy (Eds) F. Nas,-Tevfik and M. Odekon. Contributions in
Economics and Economic History Series, no. 86. Greenwood Press, Westport, CN and London, pp. 115-27. Tansel, A. (1992) Household saving, income and demographic interactions, Middle East Technical University Studies in Development, 19, 91-114. 